\title{
Reproductive Cycle of a Population of the Guaru, Phallocerus caudimaculatus (Poeciliidae), in Southeastern Brazil
}

\author{
Glauco Machado ${ }^{1}$, Ariovaldo A. Giaretta ${ }^{2}$ and Kátia G. Facure ${ }^{1}$ \\ ${ }^{1}$ Natural History Museum, Institute of Biology, State University of Campinas, Brazil \\ ${ }^{2}$ Bioscience Department, Federal University of Uberlândia, Brazil
}

\begin{abstract}
The reproductive cycle, size/fecundity relationships and seasonality in the reproduction of the poeciliid Phallocerus caudimaculatus were studied in Southeastern Brazil. There was a positive correlation between the monthly proportion of females with offspring and the day length and between female's size and offspring number. The reproductive period starts in November, when most of the females carry embryos. From January to March a decrease was observed in the number of females carrying eggs and an increase in the number of the non-reproductive females. Greater microhabitat availability, food supply and warmer temperatures may provide optimal conditions for growth of juvenile $P$. caudimaculatus in the wet-warm season.
\end{abstract}

Keywords: Phallocerus, reproductive cycle, seasonality, fecundity, Poeciliidae.

\section{Introduction}

Life history patterns result from both evolutionary forces and immediate responses to environmental conditions. Therefore, reproduction can be seasonal even in tropical regions (Winemiller, 1989). Poeciliids are small, predominantly ovoviviparous and viviparous fishes (Thibault \& Schultz, 1978) of tropical and subtropical latitudes of the New World, mainly in South and Central America (Meffe \& Snelson, 1989). With regard to reproduction, this family shows several particularities, including sperm storage by females (Constantz, 1989), production of mixed paternity clutches (Constantz, 1984), and superfetation, i.e., females carrying eggs/embryos rep- resenting two or more non-consecutive stages (Meffe, 1985; Reznick \& Miles, 1989).

The poeciliid Phallocerus caudimaculatus, regionally called 'guaru', is widespread in Southeastern Brazil (Britski, 1972). The individuals are diurnally active in shallow waters close to the margin of streams with slow or moderate current (Sabino \& Castro, 1990). As other poeciliid fishes, the guaru is viviparous and has an accentuated sexual dimorphism in size, with females larger and more robust than males (see Endler, 1983). Here we describe the reproductive cycle, size/fecundity relationships, and seasonality in reproduction of a population of guaru in Southeastern Brazil.

\section{Materials and methods}

Study site

A population of the guaru was studied at the Parque Florestal do Itapetinga $\left(23^{\circ} 10^{\prime} \mathrm{S} ; 4^{\circ} 25^{\prime} \mathrm{W}\right.$; $900-1200 \mathrm{~m}$ alt. $)$, near Atibaia, São Paulo, southeastern Brazil. The area is a microbasin formed by small perennial streams (approximately $60 \mathrm{~cm}$ wide) that flow on granitic rock or sandy beds. The climate is seasonal and has two well-defined seasons (Fig. 1). The dry-cold season lasts 4-6 months (April to September), has a mean monthly rainfall of $72 \mathrm{~mm}$, and monthly air temperatures of $17^{\circ} \mathrm{C}$, whereas the wet-warm season lasts from October to March, has a mean monthly rainfall of $182 \mathrm{~mm}$ and mean monthly air temperatures of $21^{\circ} \mathrm{C}$ (meteorological station of the Centro de Ensino e Pesquisa em Agricultura, about $11 \mathrm{~km}$ from the study site, at $770 \mathrm{~m}$ altitude). Winter frosts are frequent, especially in June and July.

Received: 13 December 1999

Accepted: 2 July 2001

Correspondence: G. Machado, Museu de História Natural, Instituto de Biologia, Universidade Estadual de Campinas, CP 6190, 13081-970, Campinas, SP - Brazil. E-mail: glaucom@unicamp.br 


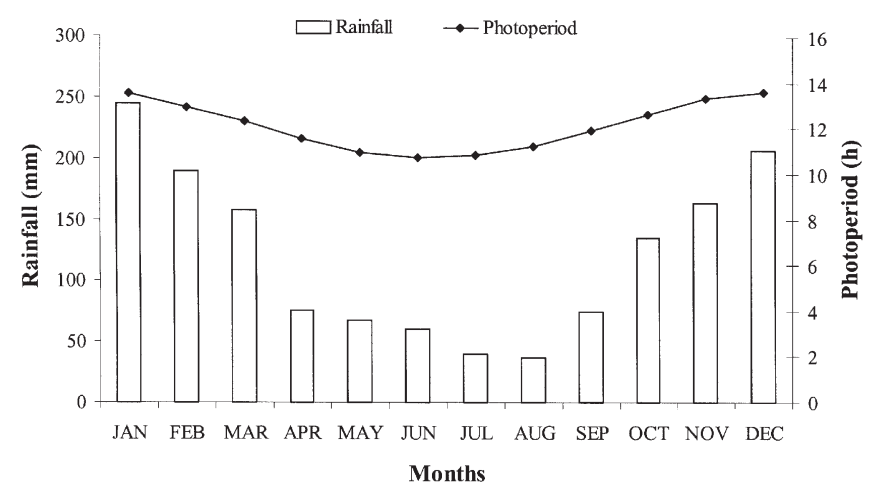

Fig. 1. Photoperiod, in hours of sunlight (line) and mean monthly rainfall (1980-94) (bars) at the Parque Florestal do Itapetinga, Southeastern Brazil. The correlation between these variables is positive and significant $\left(\mathrm{r}_{s}=0.85 ; \mathrm{p}<0.001 ; \mathrm{n}=12\right)$.

\section{Sampling of fish and analysis of reproductive status}

Specimens of Phallocerus caudimaculatus were collected in streams bordering the forest at an elevation of $1000 \mathrm{~m}$. Ten collections were made with a circular sieve $(60 \mathrm{~cm}$ diameter; $2 \mathrm{~mm}$ mesh) at intervals of 30-45 days between January and December 1994. Samples were preserved in 5\% formalin, and females were measured for standard length (SL nearest $0.02 \mathrm{~mm}$ ) with calipers. Females were dissected to record reproductive condition and size at maturity (via size of the smallest female bearing eggs). Eggs and embryos were classified based on external appearance, in each of four categories following Meffe (1985), with modifications: (a) mature and/or fertilized eggs, fully supplied by yolk and yellowish; (b) early embryos, eyes discernible but not full sized, little or no dorsal pigmentation; (c) intermediate embryos, with full sized eyes, dorsal pigmentation more accentuated and moderate yolk remaining; (d) late embryos, with little or no yolk remaining and accentuated dorsal pigmentation. Females were classified as non-reproductive when they did not fit these categories. In October and December the ovarian content was classified simply as eggs or embryos due to bad preservation of the samples.

Some poeciliid fishes may reabsorb non-fertilized eggs (Tavolga, 1949 apud Constantz, 1984), so we used 'offspring' to make reference only to embryonic stages. Voucher specimens were placed at Museu de História Natural da Unicamp (ZUEC 3269), Campinas, São Paulo State, Brazil.

\section{Results}

We analyzed 320 adult guaru females, of which 207 bore eggs or embryos. The smallest female with mature eggs was $20.6 \mathrm{~mm}$ and the largest was $38.0 \mathrm{~mm}$. Mature eggs were 1.7 $\pm 0.21 \mathrm{~mm}$ in diameter and late embryos were $8.0 \pm 1.13 \mathrm{~mm}$ in SL. No seasonal differences were found in the SL of mature females $(\mathrm{p}>0.10)$. Mean offspring number was 12.5 \pm 7.3 (range $2-39 ; n=132$ ). There was a positive correlation between the monthly proportion of females with offspring and day length $\left(\mathrm{r}_{s}=0.758 ; \mathrm{p}<0.05 ; \mathrm{n}=10\right)$, and a positive correlation between female size and offspring number $\left(\mathrm{r}_{s}=\right.$ $0.78 ; \mathrm{p}<0.001 ; \mathrm{n}=132$ ). There was no correlation between the proportion of females with offspring and mean rainfall during the study $(\mathrm{p}>0.10 ; \mathrm{n}=10)$; although it becomes positive and significant when precipitation of the following month is considered $\left(\mathrm{r}_{s}=0.67 ; \mathrm{p}<0.05 ; \mathrm{n}=10\right)$.

From April to May no female was found bearing mature eggs or early embryos (Figs. 2, 3). In July, half of the females were in a non-reproductive phase and the remaining bore only mature eggs. In August, most females carried mature eggs or early embryos. In November most of the females already carried embryos. From January to March we observed a decrease in the number of females carrying eggs and an increase of more than two fold in the number of the non-reproductive females (Fig. 2). There is a significant difference between females' fecundity at the beginning (November) and at the end (March) of the rainy season $(\mathrm{t}=$ 2.2 ; d.f. $=31 ; \mathrm{p}=0.036)$. In November, the mean offspring number $(16.4 \pm 9.6 ; \mathrm{n}=24)$ was larger than in March $(9.2 \pm$ $3.1 ; \mathrm{n}=9)$. However, the mean size of females in these months was identical $(30.1 \mathrm{~mm})$. We did not find any superfetated female.

\section{Discussion}

Under low survival conditions, the advantage of producing offspring as early as possible may outweigh the advantage of delaying reproduction and attaining a large clutch. Females that mature too late may not survive to reproduce (Kusano, 1982). For many fish species, as also shown in the present study, clutch size is positively correlated with body size of

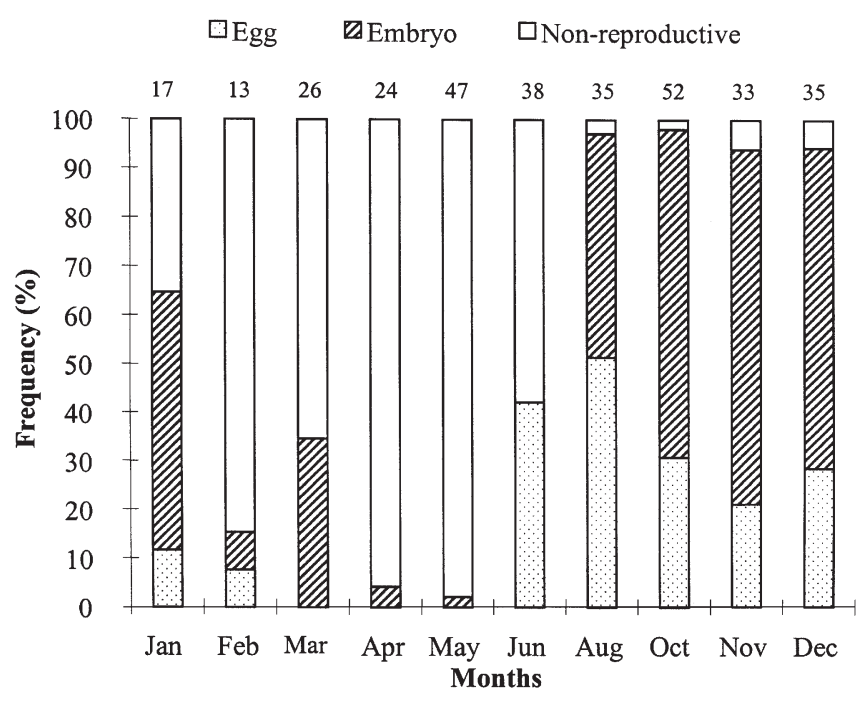

Fig. 2. Reproductive condition of females of the guaru, Phallocerus caudimaculatus, at the Parque Florestal do Itapetinga, Southeastern Brazil. The numbers above each column correspond to the analyzed females; see text for stage definitions. 


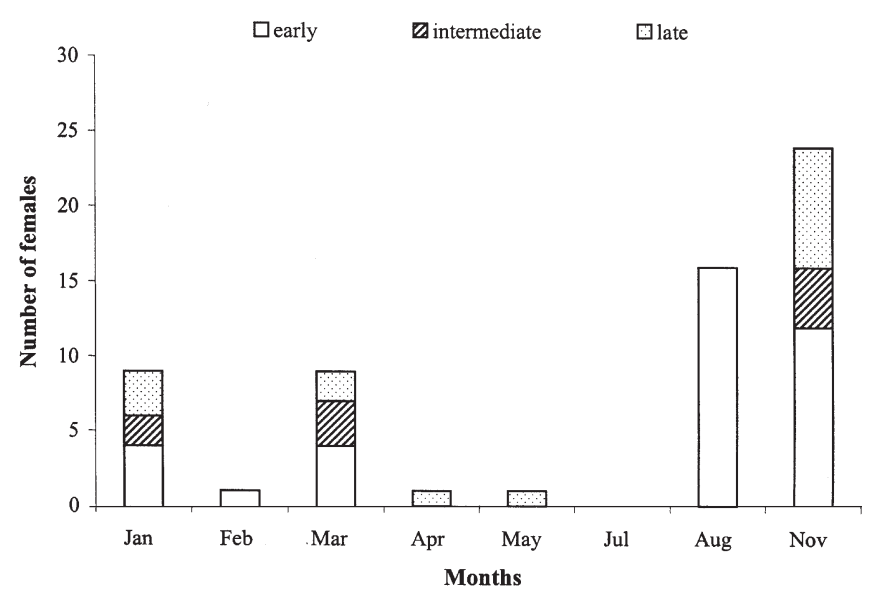

Fig. 3. Seasonal occurrence of embryonic developmental stages in females of Phallocerus caudimaculatus, at the Parque Florestal do Itapetinga, Southeastern Brazil; see text for stage definitions.

females (Reznick \& Miles, 1989; Brown-Peterson \& Peterson, 1990). Thus, according to the environmental conditions that a population is facing there are different selective pressures upon the individuals: they may reproduce early with small body size and small clutch, or they may delay sexual maturation and grow to a large body size with a large clutch (see discussion in Kusano, 1982). Phallocerus caudimaculatus females showed a wide size variation at maturity, with a consequent variation in fecundity. The precocious reproduction of the smallest guaru females may represent a strategy to guarantee at least one reproductive event before the start of the dry-cold season.

Reproduction of the guaru in Southeastern Brazil is remarkably seasonal. Eggs begin to mature in the middle drycold season, with the first matings probably occurring in June-July. The total incubation time of the guaru lasts around three months and the first juvenile recruitment occurs in October-November, in the early wet-warm season. The reproductive cycle of fresh-water fishes may be influenced by many factors including photoperiod, temperature, water flow, food abundance and nest site availability (Lowe-McConnell, 1979). The positive correlation between the day length and the frequency of guaru females with offspring indicates that the breeding season may be triggered by photoperiod, which is a good predictor of the beginning of the wet-warm season (Fig. 1). Experimental manipulations, exposing individuals to different photoperiod regime could verify this suggestion (see Norberg et al., 1995; Baggerman, 1980).

In the study site the marginal grasses of the stream are partially flooded and this may generate favorable microhabitats during the wet-warm season. In addition, the abundance of leaf litter arthropods also increases in the wet-warm season (Giaretta et al., 1999), and this certainly generates a higher inflow of food items to the streams. Allochthonous items (mainly plants and insects) are very important in the diet of fishes from forest margined rivers (Lowe-McConnell, 1987), including P. caudimaculatus. In such environments
Sabino and Castro (1990) observed that 23\% of the diet of the guaru is composed by allochthonous items. Greater microhabitat availability, food supply, and warmer temperatures may provide optimal conditions for growth of juvenile $P$. caudimaculatus in the wet-warm season, as described for other poeciliid fishes (Winemiller, 1993).

The lack of difference in size between females at the beginning and at the end of the rainy season suggests that the March recruitment is not due to newly matured females but to a second reproductive event. Even though fecundity is lower in the second reproduction, this new event may maximize the reproductive success of those females in good physiological condition. These females that breed earlier in the wet-warm season probably are able to produce an additional offspring before the beginning of the dry-cold season. The idea that the dry-cold season represents a high mortality risk period is concordant with both females reproducing when small and trying to reproduce twice during the wet-warm season.

\section{Acknowledgements}

We are grateful to R. Rosa for the species identification, A. M. Filliettaz for help in lab work, I. Sazima, W. Benson, J. Zuanon, A. Zillikens, and an anonymous reviewer for comments on the manuscript. The authors were supported by fellowships from FAPESP (proc. 96/02113-0 to GM), CNPq (proc. 104040/94-3 to AAG) and CAPES (KGF).

\section{References}

Baggerman B (1980): Photoperiodic and endogenous control of the annual reproductive cycle in teleost fishes. In: Ali MM, ed., Environmental Physiology of Fishes, New York, Plenum Press, pp. 533-567.

Britski HA (1972): Peixes de água doce do Estado de São Paulo - Sistemática. In: Poluição e Piscicultura, São Paulo, Faculdade de Saúde Pública da USP e Instituto de Pesca, pp. 79-108.

Brown-Peterson N, Peterson MS (1990): Comparative lifehistory of female mosquitofish, Gambusia affinis, in tidal freshwater and oligohaline habitats. Environm Biol Fishes 27: 33-41.

Constantz GD (1984): Sperm competition in poeciliid fishes. In: Smith RL, ed., Sperm Competition and the Evolution of Animal Mating Systems, New York, Academic Press, pp. 465-475.

Constantz GD (1989): Reproductive Biology of Poeciliid Fishes. In: Meffe GK, Snelson Jr. FF, eds., Ecology and Evolution of Livebearing Fishes (Poeciliidae), New Jersey, Prentice Hall, Englewood Cliffs, pp. 35-50.

Endler JA (1983): Natural and sexual selection on color patterns in poeciliid fishes. Environm Biol Fish 9: 173-190.

Giaretta AA, Facure KG, Sawaya RJ, Meyer JHD, Chemin N (1999): Diversity and abundance of titter frogs in a montane 
forest of southeastern Brazil: seasonal and altitudinal changes. Biotropica 31: 669-674.

Kusano T (1982): Postmetamorphic growth, survival, and age at first reproduction of the salamander, Hynobius nebulosus tokyoensis Tago in relation to a consideration on the optimal timing of first reproduction. Res Popul Ecol 24: 329-344.

Lowe-McConnell RH (1979): Ecological aspects of seasonality in fishes of tropical waters. Symp Zool Soc London 44: 219-241.

Lowe-McConnell RH (1987): Ecological Studies in Tropical Fish Communities. Cambridge, Cambridge University Press.

Meffe GK (1985): Life history patterns of Gambusia marshi (Poeciliidae) from Cuatro Ciénegas, Mexico. Copeia 1985: $762-768$.

Meffe GK, Snelson Jr. FF (1989): An ecological overview of poeciliid fishes. In: Meffe GK, Snelson Jr. FF, eds., Ecology and Evolution of Livebearing Fishes (Poeciliidae), New Jersey, Prentice Hall, Englewood Cliffs, pp. 13-31.

Norberg B, Bjönsson BT, Haux C (1995): Photoperiod controls the timing of reproduction in Atlantic Cod (Gadus morhua). In: Goetz P, Thomas P, eds., Reproductive Physiology of Fish, Austin, Fishsimp 95, pp. 167-169.

Reznick DN, Miles DB (1989): A review of life history patterns in poeciliid fishes. In: Meffe GK, Snelson Jr. FF, eds., Ecology and Evolution of Livebearing Fishes (Poeciliidae), New Jersey, Prentice Hall, Englewood Cliffs, pp. 125-148.

Sabino J, Castro RM (1990): Alimentação, período de atividade e distribuição espacial dos peixes de um riacho da floresta Atlântica (Sudeste do Brasil). Rev Bras Biol 50: 23-36.

Thibault RE, Schultz RJ (1978): Reproductive adaptations among viviparous fishes (Cyprinodontiformes: Poeciliidae). Evolution 32: 320-333.

Winemiller KO (1989): Patterns of variation in the life history among South American fishes in seasonal environments. Oecologia 81: 225-241.

Winemiller KO (1993): Seasonality of reproduction by livebearing fishes in tropical rainforest streams. Oecologia 95: 266-276. 